\title{
EFFECT OF AUDITOR'S EXPERIENCE AND ETHICS ON AUDIT QUALITY IN PUBLIC ACCOUNTANT OFFICES IN BANDUNG CITY
}

\author{
Muhammad Rizal Satria \\ Politeknik Pos Indonesia \\ rizalstr@gmail.com
}

\begin{abstract}
The purpose of this research was to know the effect of the Auditor Experience and the Auditor Ethics toward Audit Quality. The study was conducted using a survey method towards forty-five auditor who worked on thirteen public accountant firm in the city of Bandung. Data analysis was performed by multiple linear regression models. Hypothesis testing was done to determine whether there is any influence on the Auditor Experience and the Auditor Ethics towards the Audit Quality either simultaneously or partially. The test result indicates that simultaneously, the Auditor Experience and the Auditor Ethics are significantly affecting the Audit Quality. The test result also indicates that partially, either the Auditor Experience or the Auditor Ethics are significantly affecting the Audit Quality.
\end{abstract}

Keywords: Auditor Experience, Auditor Ethics, Audit Quality.

\section{Introduction}

Public Accountant is a profession that has been trusted by the public and professional services provided by public accountants is a way to overcome the crisis of public distrust of the financial statements of an entity or organization. The public accounting profession is a profession that requires the executor to be impartial in taking responsibility for management reports in a company. The public accounting profession is responsible for raising the level of reliability of a company's financial statements so that the public obtains reliable financial information as a basis for making decisions (Dina et al., 2013: 2)

In carrying out his profession, public accountants are required to produce quality audits. Every job must pay attention to the quality of services rendered, including the quality of audits provided by the auditor. The higher the audit quality, the higher the trust of information users such as potential investors, investors, creditors, the government, and the public to use financial statements. (Martin, 2013: 3 ). Audit quality is a probability that an auditor finds and reports about a violation in the company's accounting system in the audit. Moreover, in measuring audit quality, there are many considerations, according to Parasuraman et al. in Stefhanie (2012: 13) states that there are five dimensions

In determining the quality of audit services, namely "Reliability, Responsiveness (Speed of responding to findings), Assurance (ability to guarantee clients), Empathy (including dimensions of Access, Communication, and
Understanding of clients) and Tangibles (ability) to assess and understand real assets)." Sound quality will support performance even able to boost the image of an entity in public.

Thus, it can be concluded that audit quality is all possibilities where the auditor when auditing the client's financial statements can find violations that occur in the client's accounting system and report them in the audited financial statements which in carrying out their duties the auditor is guided by auditing standards and codes ethics of relevant public accountants.

Until now, there are still cases that are likely to have an impact on audit quality. Examples such as the case of the Public Accounting Firm (KAP) Drs. Mitra Winata and Partners in 2007. What caused the Minister of Finance at that time (Minister of Finance) Sri Mulyani Indrawati to freeze the permission of the Public Accountant (AP) Drs. Petrus Mitra Winata from the Public Accounting Firm (KAP) Drs. Mitra Winata and Partners for two years, starting from March 15, 2007. Head of the Public Relations Bureau of the Ministry of Finance Samsuar Said in a press release received, explained the sanction of license suspension was given because the public accountant violated the Public Accountant Professional Standards (SPAP).The violation was related to an audit of PT Muzatek Jaya's Financial Report for the year ending December 31, 2004, conducted by Petrus. Besides, Petrus has also violated restrictions on general audit assignments by conducting public audits of the 
financial statements of PT Muzatek Jaya, PT Luhur Artha Kencana and Nuansa Hijau Apartments from 2001 to 2004 fiscal year (source: https: //www.hukumonline. com).

The violation is undoubtedly deplorable because the public accountant's code of ethics that limits the maximum accounting period for independent accountants is certainly not without reason. This code of ethics regulates professional responsibilities, competencies, and professional prudence, confidentiality, professional behavior, and technical standards applied by an auditor in carrying out his profession.

In order to be able to support his professionalism as a public accountant, the auditor in carrying out his audit duties must adhere to the audit standards set by the organization that oversees them, and in Indonesia in this case the Indonesian Accountants Association (IAI), namely general standards, standards of fieldwork, and reporting standards. However, in addition to the audit standard, public accountants also need to comply with a professional code of ethics that regulates the behavior of public accountants in carrying out their professional practices well between fellow members and the wider community.

The development of ethical and moral awareness plays a vital role in all professions, including the public accountant profession in shaping the nature and professional behavior of accountants which can have an impact on the quality of audits produced. Several definitions of ethics have been revealed in previous studies. As will be explained below:

Maryani \& Ludigdo in Dina et al. (2013: 2) interpret ethics as "a set of rules or norms or guidelines governing human behavior, both those that must be done and those that must be abandoned which are adhered to by a group or group of people or society or profession."

Based on the above definition, it can be concluded that ethics is a rule that includes values and norms that govern human behavior or attitudes in community life patterns, including in the scope of profession, the perspective of the public accountant profession, an auditor is required to have an ethical awareness level above average when doing their job, namely checking financial statements. That way, the opinion he gets will also be in accordance with the reality of the company's financial condition that has been audited.

Then, the experience is a supporting factor for each individual or group in the field of work performed. The more experience they have, the more expertise they have, the following definition will give a little explanation of the experience. "Experience is a learning process and the development of potential behavioral increases, both from formal and non-formal education or it can also interpreted as a process that brings someone to a pattern of higher behavior "In Fransiska et al. (2014: 3).

Therefore, it can be concluded that work experience, both directly and indirectly, will add to the auditor's expertise in carrying out his duties. This expertise enables the auditor to indicate risks in an entity or company. Adequate knowledge is even a qualification for auditors to accept audit engagements.

In this study, the authors used Dina Purnamasari and Erna Hernawati's previous journal in 2013 entitled "The Effect of Auditor Ethics, Experience, Knowledge, and Dysfunctional Behavior on Audit Quality", then Fransiska Kovinna and Betri's 2014 journal entitled "The Effect of Independence, Work Experience, Competence and Ethics of Auditors on Audit Quality ", as well as Milos Jelic's 2012 international journal entitled" The Impact of Ethics on Quality Audit Results ". Moreover, the results of their research, Fransiska Kovinna and Betri (2014), as well as Dina Purnamasari and Erna Hernawati stated that the Auditor's Experience and Ethics simultaneously had a significant effect on Audit Quality. Meanwhile, research Milos Jelic (2012) says Ethics does not have a substantial impact on audit quality.

Therefore, the authors feel the need to carry out this study which has been given the title "The Effect of Auditor's Experience and Ethics on Audit Quality" which will be carried out in a Public Accountant Office located in Bandung, West Java, Indonesia to examine how the experience and ethics influence auditor on the quality of audits conducted by independent auditors in the Bandung area.

\section{Method}

The research used in this research is explanatory research or analytical research. Namely, a study that is expected to answer specific questions or hypotheses that can achieve good validity. The object of this research is the work experience, 
auditor ethics, and audit quality whereas the research subjects are chosen in this study were auditors from partners, senior auditors, junior auditors, etc. in KAP in the city of Bandung that were the object of research. The data collected in this study were obtained using a survey method that is distributing questionnaires to each individual personally (personally administered questionnaires), which is to find out how much influence the auditor's experience, and the auditor's professional ethics. Moreover, the criteria for scoring for alternative answers from each item are as follows: (1) Score 1 for strongly Disagree answers, (2) Score 2 for Disagree answers, (3) Score 3 for Neutral solutions, (4) Score 4 for Agree answers, (5) Score 5 for Very Agree with answers. Besides, researchers will also use secondary data to supplement research data derived from journals, articles, and other literature books.
Analysis of the data used in this study is the analysis of qualitative and quantitative data. Analysis of qualitative data that has been framed, namely by elaborating and evaluating the results of the distribution of questionnaires, then scoring. Qualitative analysis, namely explaining which factors most influence the auditor on audit quality, with sentences derived from statistical tests on the distribution of questionnaires to respondents. Quantitative analysis is used to see the results of the questionnaire using tabulation in the form of an assessment of the results of filling out the questionnaire. The analysis technique that will be used in this study is to use statistical analysis, namely the t-test and F test with the SPSS 23.0 program. This research also uses validity, reliability, normality test, multiple correlation test, multiple linear regression analysis test, coefficient of determination test, and hypothesis testing.

The formulas used to test multiple linear regression analysis are as follows:

$Y=a+b 1 \times 1+b 2 \times 2+b 3 \times 3+b 4 \times 4+e$

\section{Persamaan 1: Persamaan Regresi Linear Berganda}

\section{Results}

This research was conducted by distributing questionnaires to $13 \mathrm{KAP}$ in the city of Bandung, with a total of 52 auditor respondents. In this study, only 45 data returned questionnaires with a data return ratio above $80 \%$. Here are the results of the processing of these data

\begin{tabular}{ccc}
\multicolumn{3}{c}{ Table 1. Validity Test } \\
\hline \\
\hline Pernyataan & R Hitung & R Tabel \\
\hline Auditor Experience (X1) & & \\
\hline 1. & 0,661 & 0.295 \\
\hline 3. & 0,399 & 0.295 \\
\hline 4. & 0,570 & 0.295 \\
\hline 5. & 0,531 & 0.295 \\
\hline 6. & 0,504 & 0.295 \\
\hline 7. & 0,649 & 0.295 \\
\hline 9. & 0,488 & 0.295 \\
\hline 10. & 0,568 & 0.295 \\
\hline Auditor Ethics (X2) & & 0.295 \\
\hline 1. & 0,560 & 0.295 \\
\hline 2. & 0,518 & 0.295 \\
\hline 3. & 0,482 & 0.295 \\
\hline 4. & 0,521 & 0.295 \\
\hline 5. & 0,437 & 0.295 \\
\hline 6. & 0,514 & 0.295 \\
\hline 7. & 0,454 &
\end{tabular}




\begin{tabular}{ccc}
\hline 8. & 0,489 & 0.295 \\
\hline 9. & 0,597 & 0.295 \\
\hline 10. & 0,525 & 0.295 \\
\hline Audit Quality (Y) & & \\
\hline 1. & 0,632 & 0.295 \\
\hline 2. & 0,768 & 0.295 \\
\hline 4. & 0,542 & 0.295 \\
\hline 5. & 0,491 & 0.295 \\
\hline 6. & 0,607 & 0.295 \\
\hline 7. & 0,594 & 0.295 \\
\hline 8. & 0,426 & 0.295 \\
\hline 9. & 0,491 & 0.295 \\
\hline 10. & 0,524 & 0.295
\end{tabular}

Table 2. Reliability Test

\begin{tabular}{|c|c|c|c|}
\hline \multicolumn{2}{|l|}{ Variabel } & $\begin{array}{c}\text { Cronbachs } \\
\text { Alpha }\end{array}$ & $\begin{array}{c}\text { Standard } \\
\text { Alpha }\end{array}$ \\
\hline \multicolumn{2}{|c|}{$\begin{array}{l}\text { Auditor } \\
\text { Experience } \\
\text { (X1) }\end{array}$} & 0,664 & 0,60 \\
\hline \multicolumn{2}{|c|}{$\begin{array}{l}\text { Auditor Ethics } \\
(\mathrm{X} 2)\end{array}$} & 0,685 & 0,60 \\
\hline \multicolumn{2}{|c|}{$\begin{array}{l}\text { Audit Quality } \\
(\mathrm{Y})\end{array}$} & 0,727 & 0,60 \\
\hline \multicolumn{4}{|c|}{ Table 3. Normality Test } \\
\hline $\mathrm{X} 1$ & $\times 2$ & $Y$ & $\begin{array}{c}\text { Unstandardized } \\
\text { Residual } \\
\end{array}$ \\
\hline 45 & 45 & 45 & 45 \\
\hline 33,1778 & 43,1556 & 38,4444 &, 0000000 \\
\hline 2,00328 & 2,54911 & 2,58980 & 1,99796701 \\
\hline 170 & 124 & 104 & .129 \\
\hline , 141 & .124 & ,104 & 129 \\
\hline,- 170 &,- 120 &,- 084 &,- 117 \\
\hline .170 & 124 & ,104 & ,129 \\
\hline, $002^{c}$ & $.079^{c}$ & $200^{<x}$ & $.059^{c}$ \\
\hline
\end{tabular}

Sumber: Hasil Pengolahan Data

From the table above shows that the significant value in the Unstandardized Residual column is 0.059 or $5.9 \%$. Thus it can be stated that the distribution of data from this study is reasonable because the results of the One-Sample
Kolmogorov Smirnov Test are more significant than 0.05 or $5 \%$. With this, it can also be stated that the data from this study has a standard data distribution and is suitable for use in further analysis. 
Table 4. Multiple Correlation Test, Rank Spearman test

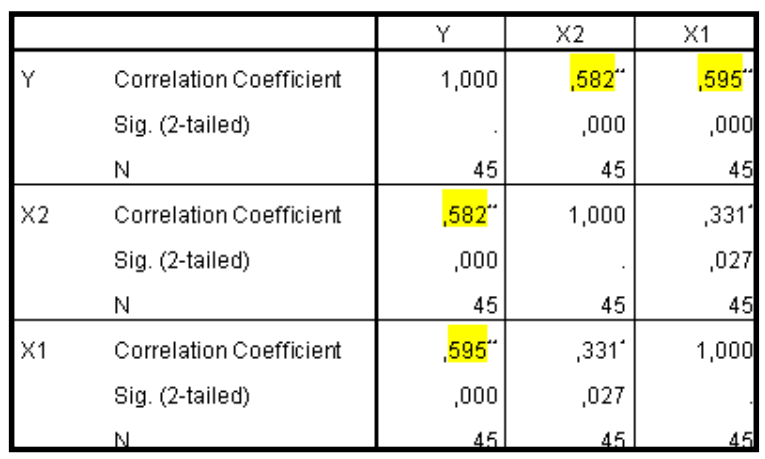

Table 6. Multiple Correlation Test

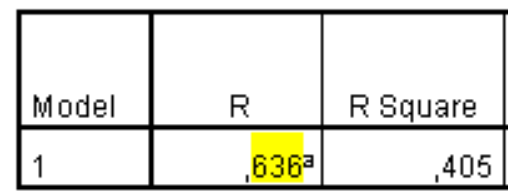

From the calculation above, it can be explained that the Spearman Rank Correlation value between the auditor's experience (X1) and Audit Quality (Y) or $\rho x 1 y$ is 0.595 . Figures $\rho x 1 y$ of The Spearman Rank correlation value between auditor ethics (X2) and audit quality (Y) or $\rho x 2 y$ is 0.582 . Figures $\rho \times 2 y$ of 0.582 indicate that there is a moderate relationship (If $0.40<\rho$ $<0.599$ means an average relationship) between auditor ethics (X2) with audit quality (Y).
0.595 indicate that there is a moderate relationship (if $0.40<\rho<0.599$ means an average relationship) between the auditor's experience $(\mathrm{X} 1)$ with audit quality $(\mathrm{Y})$.

Then the $\mathrm{R}$ number of 0.636 shows that there is a strong relationship between auditor experience (X1) and auditor ethics (X2) with audit quality (Y). This is evidenced by the measure used to interpret the strength of the weak correlation suggested by Sugiyono "if $0.60<\rho<0.799$ " means there is a healthy relationship.

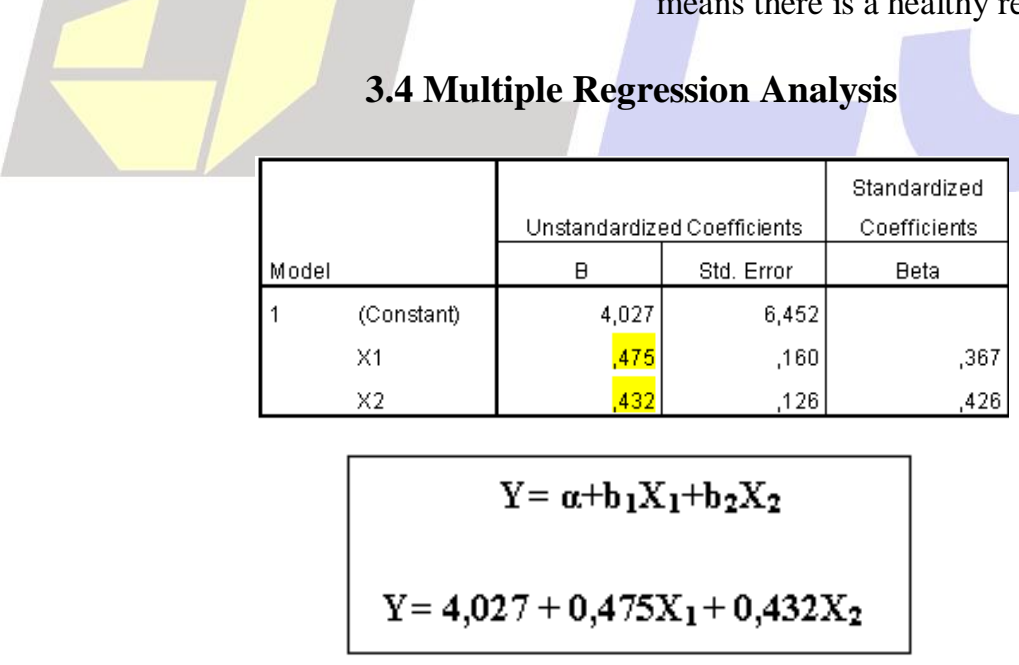

Based on the multiple regression equation above, it can be concluded that the regression coefficient b1 of 0.475 illustrates the positive influence of the auditor's experience variable (X1) on audit quality (Y), if the auditor's experience increases, the audit quality will also increase (Assuming variables auditor ethics (X2) in a constant/fixed state). Regression coefficient b2 of 0.432 illustrates the positive effect of the auditor's ethical variable (X2) on audit quality (Y), if the auditor's ethics increase, the audit quality will also increase (Assuming the auditor's experience variable (X1) in a constant/fixed state)

A constant value $(\alpha)$ of 4.027 means that if the Auditor Practices and Auditor Ethics who work 
at 13 Public Accounting Firms in the city of Bandung are constant or equal to zero (0), then the magnitude of audit quality levels produced by auditors working at Public Accountants in the city Bandung is 4,027 units.

\subsection{Coefficient of Determination}

\begin{tabular}{|l|r|r|r|}
\hline Model & R & R Square & \multicolumn{1}{c|}{$\begin{array}{l}\text { Adjusted R } \\
\text { Square }\end{array}$} \\
\hline 1 &, $636^{\mathrm{a}}$ &, 405 &, 376 \\
\hline
\end{tabular}

Based on the calculation of SPSS version 23, the is influenced by other variables not included in figure in column R2 (R Square) of 0.405 or $40.5 \%$ this research model. Also, this shows that the indicates the percentage contribution of the auditor's experience and the auditor's ethics influence of the independent variable (auditor's experience and auditor's ethics) to the dependent variable (Audit Quality) of 40.5\%, while 59, 5\% have a relationship or dependence on the quality of the audit being (if $40 \%-59 \%$ declared moderate).

\section{$3.6 \mathrm{t}$ Test}

\begin{tabular}{|c|c|c|c|c|c|c|}
\hline \multirow{2}{*}{\multicolumn{2}{|c|}{ Model }} & \multicolumn{2}{|c|}{$\begin{array}{c}\text { Unstandardized } \\
\text { Coefficients }\end{array}$} & \multirow{2}{*}{$\begin{array}{c}\text { Standardized } \\
\text { Coefficients } \\
\text { Beta } \\
\end{array}$} & \multirow[b]{2}{*}{$t$} & \multirow[b]{2}{*}{ Sig. } \\
\hline & & B & Std. Error & & & \\
\hline & (Constant) & 4,027 & 6,452 & & .624 &, 536 \\
\hline & $\mathrm{x} 1$ & .475 &, 160 & .367 & 2,960 &, 005 \\
\hline & $\times 2$ & .432 & 126 & .426 & 3,428 & ,001 \\
\hline
\end{tabular}

Based on the table above from the results of the calculation of SPSS version 23 we can know that the auditor's experience variable (X1) is 2.960 with a degree of freedom of 42 (nkl ie, 452-1), with two-party testing where the significance level is $5 \%$ or 0,05 then a table of 2.018 is obtained, so that the t-count is higher than the counter $(2.960>2.018)$. Because tcount> ttable, Ho is rejected and $\mathrm{Ha}$ is accepted. This means that there is a significant influence between the auditor's experience on audit quality at 13 public accounting firms (KAP) in the city of Bandung.
In the auditor ethics variable (X2) we can know the tcount for the auditor's ethics variable is 3,428 with a degree of freedom of 42 (nkl that is 45-2-1), with one-party testing where a significance level of $5 \%$ or 0.05 , then obtained a table of 2.018, so that the t-count is higher than the counter $(3.428>2.018)$. Because tcount $>$ ttable, Ho is rejected and $\mathrm{Ha}$ is accepted. This means that there is a significant influence between the ethics of auditors on audit quality at 13 public accounting firms (KAP) in the city of Bandung.

\subsection{F Test}

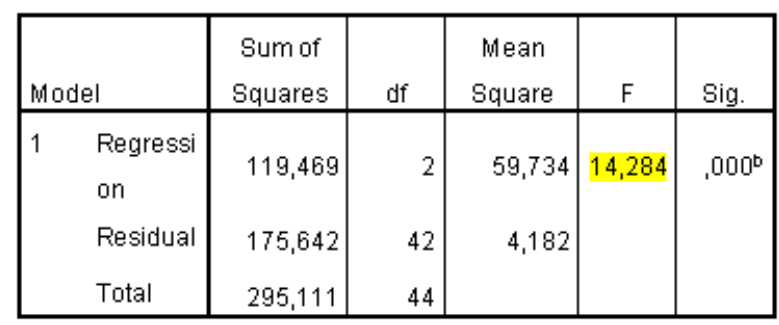

Based on the table above from the results of the calculation of SPSS version 23 we can know that the Fcount for the auditor's experience and ethics variable is 14,284 with a degree of freedom of 42 (nkl, ie 45-2-1), with one party testing where the significance level is $5 \%$ or 0.05 then obtained Ftable of 3.220, so that
Fcount is higher than Ftable (14.284> 3.220). Because Fcount $>$ Ftable, Ho is rejected and Ha is accepted. This means that there is a significant influence between the experience of auditors and auditor ethics on the quality of audit services produced at 13 Public Accounting Firms (KAP) in the city of Bandun 


\section{Conclusion}

This study aims to determine whether there is an influence of auditor experience and auditor ethics on the quality of audit services produced by auditors working at public accounting firms (KAP) in Bandung. Based on the results of research that has been done, the researcher can draw the following conclusions:

The auditor's experience partially has a significant influence on the quality of audit services produced by the auditor. These results are not following previous studies conducted by Dina Purnamasari and Erna Herawati (2013) and Fransiska Kovinna and Betri (2014). This result also supports Robyn and Peter's experience theory in Putu Septiani et al. (2014: 45)

\section{References}

Arens, Alvin A. James L. Loebbecke 2012, Modern Auditing, 12 ${ }^{\text {th }}$ Edition, New York: Pearson Education.

Arens, Alvin A., Randal J. Elder, Mark S. Beasley. 2015. Auditing dan Jasa Assurance Pendekatan Terintegrasi. Edisi 15. Jilid 1. Jakarta: Erlangga.

Elder, Randal J. dkk. 2011. Jasa Audit dan Assurance: Pendekatan Terpadu (Adaptasi Indonesia). Buku 1. Jakarta: Salemba Empat.

Futri, Putu S. Juliarsa, Gede. 2014. Pengaruh Independensi, Profesionalisme, Tingkat Pendidikan, Etika Profesi, Pengalaman, dan Kepuasan Kerja Auditor terhadap Kualitas Audit. E-Jurnal Akuntansi Universitas Udayana. 1(3): 41-58

Halim, Abdul. 2015. Auditing: Dasar-Dasar Audit Laporan Keuangan. Edisi Kelima. Jilid 1. Yogyakarta: Unit Penerbit dan Percetakan STIM YKPN.

Hanjani, Andreani. 2014. Pengaruh Etika Auditor, Pengalaman, Fee Audit, dan Motivasi Auditor terhadap Kualitas Audit. Skripsi tidak diterbitkan. Semarang: Universitas Diponegoro.

Hukumonline.com. Akuntan Publik Petrus Mitra Winata Dibekukan. Berita Hukum (Online).

(http://www.hukumonline.com/berita/ba ca/hol16423/ akuntan-publik-petrusmitra-winata-dibekukan, diakses 28 Februari 2017)

IAI (Ikatan Akuntansi Indonesia). 2011. Standar Profesional Akuntan Publik (SPAP). Jakarta: Salemba Empat.
The auditor's ethics partially has a significant influence on the quality of audit services produced by the auditor. These results are consistent with previous research conducted by Dina Purnamasari and Erna Herawati (2013) and Fransiska Kovinna and Betri (2014). However, these results are not following previous research belonging to Milos Jelic (2012). This result also supports Abdul Halim's ethical theory in his book (2015: 31). The auditor's experience and ethics simultaneously have a significant effect on the quality of audit services produced by the auditor. This supports previous research conducted by Dina Purnamasari and Erna Herawati (2013) and Fransiska Kovinna and Betri (2014).

Jelic, Milos. 2012. The Impact of Ethics on Quality Audit Results. International Journal for Quality Research, 6(4): 333342

Kovinna, Fransiska. Betri. 2014. Pengaruh Independensi, Pengalaman Kerja, Kompetensi, dan Etika Auditor terhadap Kualitas Audit. Jurnal STIE MDP, 1(1): 1-12.

Mulyadi. 2014. Auditing. Edisi ke-6, Buku 1. Jakarta: Salemba Empat.

Parera, Sthefanie C. 2015. Pengaruh Kualitas Jasa Audit dan Reputasi Terhadap Kepuasan Klien Kantor Akuntan Publik. Skripsi tidak diterbitkan. Makassar: Universitas Hassanuddin

Purnamasari, Dina. Herawati, Erna. 2013. Pengaruh Etika Auditor, Pengalaman, Pengetahuan dan Perilaku Disfungsional terhadap Kualitas Audit. Jurnal Neo-bis, 7(2): 1-17.

Putra, Nugraha Agung E. 2012. Pengaruh Kompetensi, Tekanan Waktu, Pengalaman Kerja, Etika, dan Independensi Auditor terhadap Kualitas Audit. Skripsi tidak diterbitkan. Yogyakarta: Universitas Negeri Yogyakarta.

Restuwati, Martin. 2015. Pengaruh Etika Auditor, Pengalaman, Due Professional Care, dan Perilaku Disfungsional terhadap Kualitas Audit. Skripsi tidak diterbitkan. Surakarta: Universitas Muhammadiyah Surakarta.

Sugiyono. 2016. Metode Penelitian: Kuantitatif, Kualitatif, dan $R \& D$. Cetakan ke-23. Jakarta: CV Alfabeta 